Indonesian Journal of Applied Linguistics, Vol. 2 No. I, July 20 I2, pp. I-9

\title{
A THIRD WAY: ONLINE LABS INTEGRATED WITH PRINT MATERIALS
}

\author{
Roger Palmer \\ Konan University, Japan \\ roger88@mac.com
}

\begin{abstract}
The use of ICT in language education to enhance classroom-based instruction is examined in reference to blended learning. A blended model of integrating technological advances via an online lab with a face-to-face classroom environment is presented. The example of this operating in practice is iZone, a four-level print-digital series designed with the online component called MyiZoneLab at its heart, forming a cohesive and inseparable whole with its accompanying texts. Overcoming the limitations of classroom-only instruction is a particular strength of advances in computer technology. Delivering a unified body of content through different mediums is in effect a third way, neither just online nor simply in class, and this newer model has the capability to fully exploit and reinforce the advantages of each separate medium. Online access via a web browser may make good on the promise of studying whenever the learner desires, wherever they happen to be. To this movement towards flexibility in time and place is added a further ingredient, that of choice in self-study or learning with others, and of matching the time the individual spends on tasks to their needs. Integration and inseparability are inherent in this blended model, unleashing the potentiality of technological developments in language education while seeking to transcend the either online or face-to-face learning dichotomy.
\end{abstract}

\begin{abstract}
Abstrak: Penggunaan teknologi informasi dan komunikasi dalam pendidikan bahasa untuk meningkatkan pembelajaran berbasis kelas dibahas dalam kaitannya dengan belajar secara terpadu. Model pembelajaran terpadu yang menggabungkan kemajuan teknologi melalui sebuah lab daring (online) dengan lingkungan kelas tatap muka disajikan. Salah satu contoh implementasinya adalah iZone, yaitu sebuah rangkaian digital-cetak empat tahap yang dirancang dengan komponen daring yang pusatnya disebut MyiZoneLab, yang membentuk kesatuan terpadu dan tak terpisahkan dengan teks yang menyertainya. Kemampuan mengatasi keterbatasan pengajaran dengan hanya menggunakan kelas saja merupakan kekuatan khusus dari kemajuan teknologi komputer. Menyajikan materi pembelajaran yang utuh melalui media yang berbeda akan menghasilkan modus belajar lainnya, yaitu tidak hanya daring dan di dalam kelas saja, dan model yang lebih baru ini memiliki kemampuan untuk secara penuh mengeksploitasi dan menguatkan keuntungan setiap media yang terpisah. Akses daring melalui mesin pencari dalam dunia maya menawarkan kebaikan karena memungkinkan terjadinya proses belajar dimana pun kita berada. Ke dalam pergerakan ke arah fleksibilitas dalam waktu dan tempat ini ditambahkan bahan lain, yaitu pilihan belajar mandiri atau belajar dengan orang lain, serta kecocokan waktu yang akan digunakan oleh seorang individu untuk mengerjakan tugas sesuai dengan kebutuhannya. Integrasi dan ketakterpisahan merupakan hal penting dalam model terpadu ini, sehingga dapat memicu potensi perkembangan teknologi dalam pengajaran bahasa sambil berusaha memanfaatkan sebaik-baiknya belajar baik secara daring maupun tatap muka.
\end{abstract}


Keywords: ICT (Information and Communications Technology), blended learning; online labs, F2F (face-to-face), integration

This paper investigates effective ways to apply technology in language education via iZone, a blended course that features materials developed to combine an online lab with an in-class text. It is argued that to achieve a level of integration capable of establishing blended models as genuine alternatives to either online or face-to-face modes, online labs and print materials ought to be developed as fully integrated components of a single course at the design stage. Such a fully blended solution takes advantage of technological advances to create an interdependent whole that by virtue of its structure supports and reinforces learning in a fundamental way. The approach adopted here begins with a discussion of the concept of blended learning, going on to outline how it may work when applied to the classroom. The paper situates blended learning in the context of its relevance to ELT and learners. It demonstrates how blended models are suitable for language learning especially when matching educational needs, goals and outcomes to the current generation of students. In regard to ICT use in language teaching, technology in education needs not only to satisfy instructors but also the expectations of this Millennial generation (Dziuban et al., 2004); and that necessitates its being both integrated and on demand. As online labs add to (or in other cases, replace) classroom contact hours, the question in the background is the one posed by Moore (Bonk \& Graham, 2006): when is face-toface learning support still required to supplement online learning? One hint is that learning need not be tied to a classroom at all, though a class environment lends crucial social support through the act of participation (Lantolf, 2000). The real-world application of blended technology to assist language learning is dealt with in detail, by looking at the mechanism of iZone and some practical illustrations of the ideas and features it takes advantage of, showcasing the enhanced learning capabilities that technology brings to ELT.

\section{Blended Learning}

Blended learning in ELT environments is defined in a number of ways and is often taken to be synonymous with hybrid learning, following the lead of Kaleta (2007), in which he argues that hybrid courses shift 'a significant amount' of the course learning online. One of the most straightforward definitions is that given by Dudeney and Hockly (2007), who describe it as, 'Learning which involves a combination of e-learning and face-to-face learning.' Similarly, Sharma and Barrett (2007) contend that it, 'refers to a language course which combines a face-toface (F2F) classroom component with an appropriate use of technology.' Within the scope of this paper, the concept is one of a blended print-digital course, in which the textual material is integrated with the online learning centre, MyiZoneLab, the area containing the core course study plan and resources. This is invariably the first and last place students go to study and access key information. In-class directed learning with an instructor presents the same body of core content in a textbook, presented in a number of different ways, and brought to life in the classroom by the teaching professional. Moore (in Bonk \& Graham, 2006) asserts that the instructional design of the course need not be the preserve of the teacher, and indeed the instructor's time could be better spent aiding learners as individuals, bringing 
out and helping to make sense of the key areas of study. This notion gives a key insight into the third way which has yet to take hold fully in the ELT profession: namely that by blending the knowledge of materials designers as experts with the instructor's skill in-class, helping to liberate the teacher's creativity and the learner's potential, blended learning works as an efficient division of labour (Moore, ibid). This has important implications when considering the multitude of demands placed on teachers in a hi-tech world; for the blended model fully embraces technology in the classroom at the planning and execution stage, unlike conventional text-based language courses that may feature an associated website but generally as an addon to the course. It dispenses with the physical limitations of the CALL Lab and its cost structure, as well as the frustrations experienced by instructors acting as technicians. Online labs can be brought into the class when desirable, or left entirely as a place to go outside class.

\section{Making Blended Print-Digital Work}

A blended course can easily function as an online lab, a course book, a virtual workbook and exercise book, providing materials to cover the core skills for practice while acting as a comprehensive resource for grammar and vocabulary at each level. The content is delivered both online and in the text, with students gaining kinesthetically from typing written work and answers online as well as writing by hand in the book. The amount of time devoted to studying online is up to the learner; whereas face-to-face instruction will vary with the amount of time available to the instructor. This degree of built-in flexibility reflects changes in the teaching profession as it endeavours to cope with a fluctuating student population, offering teacher-led instruction with the text, teacher-directed study with the text and the online materials, and collaboration with peers using both the online materials and the text in the same classroom, in the same room or across campus, or virtually online outside school. Learner autonomy is implicit in a model where students take more control over their own language learning. According to Bershin (2004), blended learning makes learners feel more engaged, allows them to plan their learning over time, enables them to track their progress at each step along the way, assists them in making changes to the way they study, and helps them maintain their studies better.

\section{Generational Changes In Education}

A generational shift in the needs and expectations of Generation Y (Dziuban et al., 2004) implicitly demands that learners embrace technology to enhance study. These Millennials tend to live for today and are tuned in to technology in the moment. Research by Frand (2000), Oblinger (2003), and Dziuban et al. (2004), emphasizes that blended learning-when integrated and on demand-fits in well with their learning needs and expectations. We can reasonably assume then that our younger learners are hungry for technology and have expectations that it will be used in ELT. It is also clear that the ICT revolution, in the words of Rifkin (2009), is distributive, not centralized, and that older ideas will need to give way to new realities. Assumptions built into teacher training in the West (e.g. Thornbury \& Watkins, 2007) still largely overlook the possibilities of ICT use in teaching. For just as Generation X (those born between 1965-1980) differentiated itself from the postwar Baby Boomers by a work to live, not live to work ethic, and also by keeping productive by enjoying them- 
selves while working, so it is that the Millennials (Generation Y) distinguish themselves from their predecessors in turn, by such aspects as living for the moment, being tuned in to technology in real time, requiring clear and consistent expectations, needing to experience respect before giving it to others, and questioning everything (Frand, 2000).

Dziuban et al. (2004) emphasize that blended learning fits in extremely well with the learning needs and expectations of Millennials, for whom computers are no longer seen as technology but as an integral part of life. In the words of Signor (2009), 'if quality is maintained, blended learning has the potential to not only provide more flexibility for the students but also improved learning growth when compared to traditional face-to-face learning.' The iZone model is of the view that to guarantee quality, it is necessary to integrate the learning experience. ELT courses have been in need of technology to provide a bridge between traditional and contemporary learning. The benefits are more active and interactive student-centered instruction, increased interaction between studentteacher, student-student, student-content, and student-outside resources, and integrated assessment mechanisms for students and instructor. The online lab plus text approach is proposed as one effective delivery mechanism for integrated learning.

\section{ICT Use In Language Teaching: Izone}

iZone attempts to make good on the promise of ICT use in language instruction and learning, establishing a collaborative learning environment which uses technology to supplement and enhance traditional classroom-based communicative language teaching. By integration it is envisaged that online learning should be relevant to in-class instruction and in-class to online: students prepare online; interact face-to-face in class; and check their progress online. The online component of instruction, learning and evaluation is on demand (Dziuban et al., 2004), accessible by logging on using the password contained inside the back cover of the text. One of the great benefits of preparing online is that the pre-teaching stage normally done in class is completed before class and students are ready to study the day's unit; and it follows that class time can be devoted to other key areas of instruction without having to start anew every time. This applies not only to vocabulary, first met online and then recycled in the text, but also the unit's theme, its strategies, its video and grammatical structures. Language can thus be integrated seamlessly, as the noticing stage has been accomplished by students online studying at their own pace, and students have checked their understanding in their Gradebook where their performance is monitored and assessed. MyiZoneLab hence is effecttively multifunctional, being both a language course and a study aid, giving the instructor a degree of flexibility in how they teach the class that would otherwise be constrained by having to start from scratch. Fundamentally, iZone frees up time for communicative practice in class. Online preparation and consolidation activities occur in advance by design, and because the same body of material is presented in a different way by the instructor using the text, a greater focus can be given to communicative practice of language that has already been studied. For the students, it is a good check of what they have learnt for themselves online.

By exploiting other media such as the online video, the power of technology as a tool driving ICT is put to use in language instruction. iZone's videos employ a common core of actors who reappear throughout the course and remain in 
character, allowing students to engage with the characterization and plots. The online platform is ideally suited to the seamless integration of video with the other study material, designed with contextualization in mind. Students go into class fully prepared and at ease with the topic area and language since the video and associated comprehension exercises have set the scene and provided an embedded context in the minds of the learner as a pre-task activity. Such schema-building tasks focusing on bottomup processing skills are normally difficult to prepare and execute for instructors, not to mention time-consuming. Taking what is normally one of the most challenging inclass aspects of teaching and making it a positive instructional feature online is a strength of the blended model. Students have control over the video clips and can open up boxes to view the transcripts whenever they need support. Furthermore, the video clips and interactive activities are combined with the Zoom in! language feature, a teaching tool with information on useful phrases and spoken English.

Beyond these familiar uses of technology for online preparation and using video to the full, however, until now there has been a perceived defect, for technology in language pedagogy has struggled with the notion that it only mimics face-to-face learning and adds little more; but with online labs at the core of the course and printed materials in support, technology can be said to have undergone a transformation into enhanced learning. So while blended learning is hardly a recent educational phenomenon (Dziuban et al., 2004), the capabilities that exist today mean that there are new and innovative ways of language study in web-based learning environments, and those environments in turn are constantly evolving online. Features including the use of avatars, instant feedback, learner control over the video tasks already outlined, and interactive role plays, signify a significant shift in online education away from imitating classroom methods and practices. MyiZoneLab adds further enhancements to be used at the discretion of the teacher, extending to course overviews and lesson plans, the online Gradebook, quizzes and tests, options on setting pass levels, receiving alerts on student performance, audio and video with transcripts, file uploading capability, a discussion board feature, and useful links. The online labs can be said to take teaching and learning on to a new level.

Another characteristic of iZone's approach to blended learning is the immediacy of feedback on one's progress online, a highly effective motivational tool pertaining to online labs; and it can be argued that this kind of learning helps learners to cope with the normal motivational peaks and troughs of language study. It assists in what is termed 'initial motivation' (Dörnyei, 2001), when learners are motivated by the innate value of language learning, since technology can easily harness high student interest in phones or computers or gaming devices and connect it with L2 learning. Indeed, MyiZoneLab takes advantage of positive attitudes towards technology, providing as it does online games that recycle language from the units in a stimulating and competitive milieu. To maintain motivation and stop it from ebbing away, giving students real choices over what they learn is enabled by promoting learner autonomy (Dörnyei, 2001). An online lab that encourages self-study and flexibility in how much time to spend on tasks is of benefit in this process. The very nature of feedback, through the Gradebook which records scores or the teacher marking online written work after submission, is a strength built into the instructional design of iZone. Moreover, blended learning acknowledges that learners may need to engage with material in a variety of ways to aid comprehension and retention. This is relevant to the 
current debate in English teaching on a 'principled eclecticism' in methodology (Harmer, 2007), with a need identified for teaching that satisfies the three strands of Engaging (the interest) of students, having them Study (alone and in groups), and Activating what they know and what they are learning (hence ESA). Without being tied to the four walls of a classroom, students study experientially by doing as well as by trial and error online. Rather than soaking up information, students activate their skills on a number of levels at the same time as studying language. They need to interact with a computer as they follow the log in instructions, and they need to read and respond to prompts along the way. They are asked to navigate their own way through, choosing what to study, selecting their own path, and leaving other parts to come back to later. This level of engagement differs greatly from a class where everyone studies in lockstep with the teacher, and when the physical space is determined for the students by someone else.

For students to benefit more fully from online labs, a move towards fuller learner autonomy can be supported by equipping students with greater technological resources. Both language (via the Zoom in! resource) and grammar (via the Grammar zone resource) help learning in a structured sense by way of example, occurring at just the time students encounter the target item. Drawing on the Longman Corpus Network, iZone has access to a massive collection of spoken and written texts drawn from newspapers, books, radio, television and everyday conversations. Help is only ever a click of the mouse away, and the technology works in the background to allow students to draw on it when needed. As far as possible, content is matched to needs and is summoned up within the online lab at will. Similarly, avatars give life to strategy training in ways that were considered impossible before. These iTutors are as described, tutoring students as they introduce strategies for communication and pronunciation, providing examples of the strategy in use, and speaking as a virtual person to the learner. Through the online lab, this one-onone coaching has numerous benefits; for unlike a teacher speaking in unprepared discourse, the language the avatar uses is planned to be closer to the level of the listener; and the message is conveyed through the eyes by viewing the i-Tutor avatar, through the ears by listening to their message, and is capable of being crossreferred to the text on the screen. Such strategy training can be repeated as many times as necessary to become proficient in terms of fluency and accuracy. The process adopted in iZone also acknowledges that strategies need to be noticed, taught and practised just like any other aspect of language.

Learner training does have its limitations, however, and iZone recognizes that spoken practice and interaction in the classroom with peers and an instructor does not guarantee progress. Hence spoken interaction is built into the online lab. Role plays, for example, are part of every unit in the Prepare stage, and students can take on the roles at anytime, wherever they log on, free from the need for a native English-speaking partner or teacher, and free from the confines of the classroom. Students can be both the person initiating the dialogue and the person responding. Crucially, this kind of practice allows for a space in which the students engage in planned discourse, before the more stressful unplanned interactions common to the classroom. The scaffolding of the task offers as much support as necessary until it is time to engage in the same structured conversations with classmates and a teacher in class, and later moving on to freer and less structured spoken discourse 
without the support. It also provides crucial practice in the kinds of speaking tasks common to Internet-based tests of English. Face-to-face learning performance correspondingly benefits after the autonomous learning phase has been fully exploited. With the thorough additional preparation completed online, students come to class readier to launch into directed in-class learning, fully cognizant of the integrated nature of iZone's approach. The burden on the teacher is eased, since acculturation to the aims of the class is handled in advance.

It starts to become clearer, then, what is meant by the print-digital third way represented by iZone: it 'triangulates' into selfstudy, online-facilitated learning, and faceto-face facilitated learning, with pragmatic implications for instructors, learners, and how they interact in their changing roles (Heinze, 2008). At the pedagogical level, blended courses impact on communication, social interaction and assessment (Heinze, 2008). There is a consolidation stage between online Prepare and the in-class presentation forming a bridge in the learning process: students come to class having studied the context and language and strategies and thought about the topic for themselves. Students will have questions about things they want to know more about or need clarification on. The instructor can introduce the in-class study by reviewing the online study; have students record their online scores as a check; expand on what has been introduced; and clarify the unit goals. Likewise, Listen and respond or Read and respond introduce the same basic body of material unified with the online lab but presented in new ways. This multi-layered approach takes learning deeper and wider. For example, the same item of vocabulary is recycled in several different contexts, and collocates with a variety of other words. The strategic language is reintroduced in the text as Strategy in action, offering options for listening to and practicing the communication strategy. Each step of the way, learning is built up, reconfigured, and consolidated before moving on. Language in action, using data from the Longman Grammar of Spoken and Written English, builds on this triangle of self-study, online study and text-based study by giving students the opportunity to listen to and read the model conversation that they have previously practised in the role play online. For the contention here is that learners need to use and manipulate the language before it becomes part of their own. Model dialogues with substitutions allow students to stretch their language use beyond their own level while practicing the pronunciation point to improve their awareness of how English speakers actually speak. The fluency-based Communication task is the culmination of these efforts, and its pair and group work is the main speaking task in the unit.

Seamless integration has an additional benefit of confronting the vexed issue of what students really know and what they really learn in their language courses. iZone uses an Activity zone, which is a lighter pair or group speaking activity taking the unit theme to reinforce learning through use. Words and phrases from the unit are again recycled, since there is no assumption that students will really know a word until they have met it countless times. This constant reinforcement takes for granted the notion that some forgetting is normal in the process of language learning and that knowing a word in all its meanings and uses and collocations is a stiff challenge. By bringing back words and putting them to work in the conscious mind, more connections are made between and among different meanings. Students can then apply the language more freely and act out their own scripts using the Video extras, with the option of watching the full online video in class. There is also a Checkpoint where students are pushed to 
think about and evaluate the usefulness of what they've learned by considering what they have enjoyed and found useful in the unit, and then assigning scores on a scale. This notion of ranking and expressing personal choices extends to a whole range of options in Online Extras. Features include the full version of the video with online activities, with students given the choice of how much and what type of study is appropriate to their needs. Students are encouraged to give free range to their selfexpression in the optional Writing tasks. Through writing emails, letters and other text types in English, they learn to express their own ideas in their own words. Again, these types of tasks are ideal for practice in Internet-based tests. Furthermore, instructors can choose to respond to the writing and edit the work their students produce. One other important feature is the online game, which helps develop creative problem solving abilities through word puzzles and competitive tasks. This is certainly another advantage of ICT use in education, for such technological means of achieving educational goals via blended learning open up new possibilities.

Online labs have yet another advantage, as an efficient forum for testing, but it is important to see why testing can act as a positive aid to learning. The Quiz built into iZone is not an add-on but an essential feature to help learners find out precisely how much they have understood and can remember; yet it is much more than that. The Quiz is seamlessly integrated into the course to bridge the in-class and online parts of the course to give students immediate feedback on their progress. Testing acts as a powerful learning tool, and according to recent research (Carey, 2010) it is the very difficulty of tests (so-called "desirable difficulty") that makes them so effective. The hard challenge of having to recall something that has been learned makes it that much harder to later forget. Hence testing takes place online after every unit, as well as at mid-term, and at the end of the course. For the students, they have access to their grades and other resources precisely because of the blended structure. Oblinger (2003) describes how the Millennial generation demands experiential, interactive and authentic learning, which blended courses are able to provide. Information should be provided on demand, and waiting for the following week's class to investigate questions no longer satisfies the cravings for answers now. Blended learning fills the gap between learner expectations of an online experience of gaining new knowledge and skills and the face-to-face only reality they are still offered by schools that have not made the change. Online laboratories such as MyizoneLab thus enable learners to have rich learning experiences without limitations. For the instructors, what it means is that what they need is always accessible online. They can upload files to their class lab for students to view; they can find lesson plans with answer keys, unit quizzes, mid-term and semester tests, audio scripts and page scans. Functionality and time-saving are built in, which means that resources the teacher does not require at that time are hidden away. The Gradebook is organised for the instructor to view students' scores and other data such as time spent on tasks. Useful links and resources are also available to enhance professional development, along with a discussion board. It is set up in such a way to foster research that can inform teaching, and teaching that can inform research into language instruction.

\section{Conclusion}

This paper has sought to outline what blended learning is, the ways in which the 
model is effective for language learning, its relevance and applicability in language education for the current generation of students, and the practical application of such a delivery mechanism by looking at iZone its MyiZoneLab in detail. Blended learning benefits as shown from being an approach that brings together the educational effectiveness and dynamic communicative environment of the classroom with the equally dynamic, technologically-driven efficiency and continual evolution of the online learning milieu. Blended learning as an approach combines the social participation of the classroom with the technologically enhanced active learning possibilities found online. The concept of a third way will not be the last word in ELT, but at the very least as a transitional stage it shows the possibilities available right now. It meets the expectation of learners, and places their needs and choices closer to the heart of learning. In so doing, it challenges the criticism that technology interferes in the learning process, and starts to ask whether so much face-to-face instruction alone can succeed. It is hoped that the showcasing of the author's own design of a blended environment in the presentation of this paper will lead to a fuller appreciation of blended learning's significance in ELT; and that technology can be the driving force for integrated learning to blossom.

\section{References}

Bershin, J. (2004). The blended book of learning. San Francisco: Pfeiffer.

Bonk, C. \& Graham, C., eds. (2006). Handbook of blended learning: Global perspectives, local designs. San Francisco, CA: Pfeiffer Publishing.

Carey, Benedict. (2010). Forget what you know about good study habits. New York Times, September 6, 2010
Dörnyei, Z. (2001). Motivational strategies in the language classroom. Cambridge: Cambridge University Press.

Dudeney, G., and Hockly, N. (2007). How to teach English with technology. Harlow, UK: Pearson Education.

Dziuban, C., Hartman, J., \& Moskal, P. (2004). Blended learning. EDUCAUSE Center for Applied Research, Research Bulletin Vol. 2004, Issue 7. ECAR: Colorado

Frand, Jason (2000, September/October). The information age mindset: Changes in students and implications for higher education. EDUCAUSE Center for Applied Research, Review 35(5), pp.15-24 ECAR: Colorado

Harmer, J. (2007). How to teach English. Harlow, UK: Pearson Education.

Heinze. A (2008). Blended learning: an interpretive action research study. PhD Viva presentation. 15th May 2008. University of Salford, Salford, UK. Retrieved online on September 5, 2009 http://www.aheinze.me.uk/

Kaleta, Robert (2007). Creating the Hybrid Class. Notes, pp.6-14. STARLINK: Dallas. Retrieved on http://www4.uwm.edu/ltc/hybrid/

Lantolf, J. (ed.) (2000). Sociocultural theory and second language learning. Oxford: Oxford University Press.

Oblinger, D. (2003). Boomers Gen-Xers, and Millennials: Understanding the 'New Students. EDUCAUSE Review, 38(4), pp. 37-47, <http://www.educause.edu/ir/library/ pdf/erm0342.pdf>

Rifkin, J. (2009). The empathic civilization: The race to global consciousness in a world in crisis. Los Angeles, CA: Tarcher

Sharma, P. and Barrett, B. (2007). Blended learning. Oxford, UK: Macmillan Education: 
Signor, L. (2009). Blended Learning versus Traditional Face-to-face Learning. VDM Verlag Dr. Muller: Saarbrucken, Germany

Thornbury, S. \& Watkins, P. (2007). The CELTA Course. Cambridge, UK: CUP
Wenger, M. and Ferguson, C. A Learning Ecology Model for Blended Learning from Sun Microsystems. In Bonk, C. \& Graham, C., eds. (2006). Handbook of blended learning: Global perspectives, local designs. San Francisco, CA: Pfeiffer Publishing. 